\title{
The Relationship between the Risk of a Change of the Interest Rate and the Age of Entrepreneurs among Slovak SMEs
}

\author{
- Sobeková Majková Monika
}

\begin{abstract}
Young entrepreneurs and start-up founders are considered to be a drivers of innovation which is an important element of knowledge economy and competitiveness of each country. But their early age could be perceived as a factor causing the increasing impact of the credit risk because young entrepreneurs usually have a short company history, weak capital power and a lack of the guarantees. The main objective of this paper is to bring scientific evidence that the age of the entrepreneur should be considered as a factor with the significant impact on one part of the credit risk of a company- the risk of a change of the interest rate. The research was carried out among 438 Slovak companies in 2016. Based on Pearson's chi-square analysis of the results of our research, we bring statistical evidence that age has a significant impact on the ability of the company to protect the firm against the change of the interest rate. We also found out that there is dependence between the age of the owner and the opinion that SMEs in the other EU countries have better loan conditions, especially lower interest rates, than Slovak SMEs. Research findings indicate that young entrepreneurs have problems with obtaining capital and increasing interest rates and collaterals because of their higher risk profile. But effective state support of young and innovative companies through venture financing can lead to increasing global competitiveness of the Slovak Republic.
\end{abstract}

Keywords: young entrepreneurs, venture firms, start-up, SMEs, credit risk, interest rate risk JEL Classification: G11, G32

\section{INTRODUCTION}

Small and medium-sized enterprises (SMEs) are the backbone of each market economy (Sobeková - Majková, 2011; Karpak and Topcu, 2010). Their share on total number of companies in the EU, the US and also in Slovakia is almost 99 \% (Bhaird, 2010;Belás et al., 2015a, Kozubíková et al., 2015;Sobeková - Majková, 2011). Their small size is according to such authors as Steinerowska-Streb and Steiner (2014), Irwin and Scott (2010), Mercieca et al. (2009), Belás (2015b), Dong and Men (2014), Cheng, Tang and Shi (2012) often a reason why they more intensively face the financial risk and also the credit risk. Also Vos et al. (2007), Bottazzi et al. (2014), Lazányi (2014), Oliveira and Fortunato (2006), Dong and Men (2014), Hernández-Cánovas and Martínez-Solano (2010), Bougheas et al. (2006), Pickernell et al. (2011), Riding et al. (2012) declare that the credit risk is higher in the group of younger entrepreneurs. The aim of this paper is to prove by the statistical method that the age of entrepreneurs (SMEs) should be considered as a relevant factor with the significant impact on the intense of credit risk in general, and its part - the risk of a change of the interest rate - in particular in Slovakia. Based on the results from 
the research carried out among Slovak SMEs in 2016 we found out that there is a dependence between the age of owner and the ability to manage interest rate risk, and also between the age of the entrepreneur and the opinion that SMEs in other EU countries have better loan conditions, especially lower interest rates, than Slovak SMEs.

\section{LITERATURE REVIEW}

SMEs play a significant role in each market economy (Sobeková - Majková, 2011 and Karpak and Topcu, 2010) and in economic growth (Beck and Demigruc-Kunt, 2006). But their size has a significant impact on the availability of suitable capital for them. Dong and Men (2014) and Abor et al. (2014) consider the limited access to external financing including bank loans as one of SMEs growth obstacle. Several other authors like Garwe and Fatoki (2012), Roper and Scott (2009), Mijid (2009), Constantinidis et al. (2006), Zwan et al. (2010), Mama and Ewoudou (2010), Freel et al. (2010), Nkundabanyanga et al. (2014), Ključnikov and Belás (2016) and Krasniqi (2010), etc. devote their attention to this topic. Young entrepreneurs are a special segment of SMEs. Belás and Sobeková (2016) explain that young companies and start-ups are the drivers of innovation, but they face the credit risk more intensively than others. Young entrepreneurs often have problems with collateral requirements and raising interest rate in the process of obtaining a bank loan.

Many authors declare that firm size is a relevant factor of financial and credit risk all over the world, including Slovakia (Beck et al., 2008; Mercieca et al., 2009; Bena and Ondko, 2012; Gambini and Zazzaro, 2013; Beck and Demigruc-Kunt, 2006; Ključnikov et al. 2016; etc.) while the external finance is having a positive impact on their growth (Gambini and Zazzaro, 2013; Behr and Guttler, 2007). According to their research, smaller companies use bank finance less responsibly than larger companies. This is also the case of Slovak SMEs (Jakubec et al., 2012).

Majková (2008) and Irwin and Scott (2010) prove that the firm size is an important factor in the assessment of credit risk. Smaller companies have the biggest problem with collateral requirements (Sobeková, 2011). Also, Cheng and Tang (2012) and Shi (2012) declare that weak capital power belongs to the most significant problems in SME financing.

Firm size has also has an impact on the interest rates for credit of SMEs. In the study of Rostamkalaei and Freel (2015), it was proven that small and growing firms in the UK are likely to have higher interest rates for credit than large firms. They present the smaller the firm is the higher the interest rates are. The results of Oliveira and Fortunato (2006) were similar.

The age of the owner is one of the significant factors with an impact on the capital structure and debt financing. Colombo, Cumming and Vismara (2016) state that these companies suffer from financing constraints, that limits their growth and menaces their survival. Lack of cash flow and collateral are ones of the main reasons in external capital rising. Many literature studies and evidences declare that venture capitalists play a crucial role in their financing.

There are not so many studies focused on the impact of age on the credit risk and company finance. Bottazzi et al. (2014) and Vos et al. (2007) bring the evidence that smaller and younger firms have more limited possibilities of external financing than larger and older firms. Vos et al. 
(2007) state that there are coherences among the age and the level of education of entrepreneur and the interest rate of drawing finance from external funds. According to their study, younger and less educated entrepreneurs are more likely to use external finance for their business growth, while older and more educated entrepreneurs are less likely to use external financing. According to Lazányi (2014) younger entrepreneurs pay higher interest rates because they are of smaller firm size and their liquidity to pay in time is lower than of the older entrepreneurs. Younger entrepreneurs perceive credit risk more intensively than older. Their access to bank credit is worsened and this fact has an impact on their growth (Dong and Men, 2014). The relation between the age and the credit risk was proved in the studies of Bougheas et al. (2006), Pickernell et al. (2011) and Riding et al. (2012). According to their results, younger entrepreneurs more intensively face the credit risk than older ones.

Hernández-Cánovas and Martínez-Solano (2010) state that firms with the longer relationship with banks have an easier access to external finances, but they also get loans with higher cost. On the other hand, firms with the relationships with at least two banks get improved loan access and reduced loan costs, as well as trustful relationship between the entrepreneur and the bank. This fact indicates that the age could have an impact on credit risk; respectively older entrepreneurs with longer relationship with the banks have an easier access to bank financing and face lower credit risks. The rejections of credit or higher interest rates are mostly common for small and young firms (Oliveira and Fortunato, 2006). According to the research based on Portuguese entrepreneurs, the authors state that small and young entrepreneurs are highly cash-flow sensitive, which is caused by the fact that financial restraints are being more serious than in case of larger firms. Efficient collateral in case of young entrepreneurs can be a restraint in loan acquisition. Werner and Faulenbach (2008) found out that older entrepreneurs have fewer difficulties to get start-up finance than the younger ones.

Dong and Men (2014) and Sobeková et al. (2014) prove that small and young companies face more severe financing obstacles. Hegarty and Jones (2008) examined that the readiness after graduation and the level of use of external financing are important factors of young entrepreneurs.

The risk of a change of the interest rate as a part of credit risk was observed in the study of Neuberger and Räthke-Döppner (2014). The authors compare the interest rates in the region of East Germany with stress on demographic indicators. They bring results that young entrepreneurs are more likely to pay higher interest rates because their businesses are smaller and their liquidity to pay in time is lower than of the older entrepreneurs. This fact was also confirmed by the OECD study (2014). The study bring evidence that banks provide more finances to people with larger personal wealth which further penalises women, young and ethnicminority entrepreneurs. In principle, banks could apply higher interest rates to compensate the higher risk-profile of disadvantaged entrepreneurs. All presented studies declared relation between the age of the entrepreneurs and the interest rate risk. Coleman et al. (2014) proved that owner age is a significant factor in explaining the composition of start-up capital. They stated that young firm are more likely to access less formal debt and that the reasons for that are raising interest rates and collateral requirements. However, not all researches agree with the opinion that the age is a relevant factor of financial and credit risk. The Slovenian researcher Slavec (2014) found out that in Slovenian 
business environment the age is not negatively related to bank loans or trade credit. However, an education has more significant role in bank loans than the age of entrepreneurs.

\section{METHODOLOGY OF RESEARCH AND WORKING HYPOTHESES}

The research was focused on the current situation in Slovak business environment. It was carried out in 2016 by the questionnaire called Financial Risks of SMEs in Slovakia which was distributed online. The research data were collected by three specific ways. First, random selection of appropriate companies was made from the free database of Slovak companies available on www. vsetkyfirmy.sk. The selected companies were contacted by the research team via email. The questionnaire was also placed on specialized economic web-portals, focused on SMEs. Finally, the sample of companies selected by the team experts was contacted by the researchers directly. Total number of 438 questionnaires was collected during the research. This number of respondents fulfils the requirements for a stochastic selection.

Actual statistics (Table 1) from the Slovak Statistic Bureau declare that there were 555314 companies in 2014, of which SMEs were 554743 (99.8\%). The share of young entrepreneurs was in the basic data set $28.1 \%$, and in the sample it was $37.2 \%$.

According to the calculated sample, the research team assumed that the data are representative, and have the reliability of $95 \%$. The sampling error of $+/-5 \%$ should be considered. The minimum size of the sample should be counted by the formula $n=(1.96)^{2} \times \sqrt{ } p \times(1-p) / 0.052$ where $\mathrm{p}$ is the share of the sample. The minimum sample size was 310 , while the real size of our sample was 438.

Tab. 1 - Number of entrepreneurs in Slovakia in 2014 - comparison of the basic data set and the selected sample

\begin{tabular}{|c|c|c|c|c|}
\hline \multirow{2}{*}{ Legal Form (2014) } & \multicolumn{2}{|c|}{ Basic data set } & \multicolumn{2}{|c|}{ Selected sample } \\
\hline & $\begin{array}{c}\text { Total } \\
\text { values }\end{array}$ & $\begin{array}{c}\text { Share } \\
(\%)\end{array}$ & $\begin{array}{l}\text { Absolute } \\
\text { values }\end{array}$ & in $\%$ \\
\hline $\begin{array}{l}\text { Micro enterprises (0-9 emp.) and indi- } \\
\text { vidual entrepreneurs }\end{array}$ & 538330 & $96.9 \%$ & 287 & $65.6 \%$ \\
\hline Small enterprises (10-49 emp.) & 13743 & $2.5 \%$ & 95 & $21.7 \%$ \\
\hline Medium enterprises (50-249 emp.) & 2661 & $0,50 \%$ & 29 & $6.6 \%$ \\
\hline Large enterprises $(250+$ emp.) & 580 & $0.1 \%$ & 27 & $6.2 \%$ \\
\hline Total number of business units & 555314 & $100 \%$ & 438 & $100 \%$ \\
\hline SMEs from total & 554743 & & 411 & \\
\hline Share of SMEs in \% & $99.8 \%$ & & $93.8 \%$ & \\
\hline Young entrepreneurs up to 35 years old* & $28.1 \%$ & & $37.2 \%$ & \\
\hline
\end{tabular}

Source: Company register of the Statistical office of the Slovak Republic, own processing

*Young entrepreneur data 2012 
Regional structure of the sample was similar to the structure of basic file. Differences in each category reach values are approximately $2-4 \%$ except Bratislava and Košice region.

Tab. 2 - Comparison of the regional structure (basic data set and selected sample)

\begin{tabular}{|l|c|c|c|c|}
\hline \multirow{2}{*}{ Region } & Selected sample & Basic data set* & \multicolumn{2}{|c|}{ Difference } \\
\cline { 2 - 5 } & $\begin{array}{c}\text { Number of } \\
\text { respondents }\end{array}$ & $\begin{array}{c}\% \\
\text { of respondents }\end{array}$ & \multicolumn{2}{|c|}{$\%$ of enterprises } \\
\hline Bratislava & 199 & $45.4 \%$ & $34,70 \%$ & $10.7 \%$ \\
\hline Trnava & 28 & $6.4 \%$ & $9.2 \%$ & $-2.8 \%$ \\
\hline Nitra & 34 & $12.3 \%$ & $10 \%$ & $2.3 \%$ \\
\hline Trenčín & 44 & $10 \%$ & $8.3 \%$ & $1.7 \%$ \\
\hline Žilina & 56 & $12.8 \%$ & $9.4 \%$ & $3.4 \%$ \\
\hline Banská Bystrica & 20 & $4.6 \%$ & $8.8 \%$ & $-4.2 \%$ \\
\hline Prešov & 21 & $4.8 \%$ & $9.2 \%$ & $-4.4 \%$ \\
\hline Košice & 16 & $3.7 \%$ & $10.3 \%$ & $-6.6 \%$ \\
\hline
\end{tabular}

Source: Source NADSME 2012

According to comparison of the data in the basic data set and the selected sample, it is obvious that differences between the basic data set and the selected sample are negligible (up to $5 \%$ ). The sample contains $37.8 \%$ of service companies, $22.4 \%$ of trade companies, $13 \%$ of construction companies, $9.8 \%$ of manufactures, $8.2 \%$ of other types of companies, $4.6 \%$ of agricultural companies and $4.1 \%$ companies from transport.

The data presented in Table 1 a 2 and in previous paragraphs indicate and allow to make conclusion that the construction of selected sample and the basic data set of SMEs are virtually identical and have similar characteristics.

\section{Formulating of the Survey Hypotheses}

For the analysis of the obtained data we used Microsoft Excel (Office 2007) and its possibilities in the data processing using pivot tables. The tools of descriptive statistics (averages and percentage) were important research instruments. The methods of comparison and deduction were used for the data analysis. A statistical method of Pearson's chi-square at the significance level of $5 \%$ was applied by using the statistical software available at www.socscistatistics.com for the verification of the existence of the statistically significant dependences and differences between the selected factors. If the calculated p-value was lower than $5 \%$, the null hypothesis was rejected, and the alternative hypothesis was adopted. Due to the length limitations the paper presents the results of some selected problems. Arguments were built according to experience and estimations of the research team.

The each alternative hypothesis was assigned with a null hypothesis that assumes that there are no statistical verified differences between observed groups 
Null hypothesis: $\pi_{1}=\pi_{2}$ so $\pi_{1}-\pi_{2}=0$

Alternative hypothesis: $\pi_{1}-\pi_{2} \neq 0$

The research was focused on the impact of the age in relation to the special type of credit risk - the risk of the change of the interest rate. The author defined two alternative working hypotheses (H1, H2), the accuracy of which was verified by the statistical methods. Formulation of the null bypothesis was as follows: There is not statistically significant dependence between the age and the perception of the interest rate risk on the Slovak financial market.

H1: There is a statistical significant dependence between the age and ability of company to protect against change of the interest rate.

H2: There is a statistical significant dependence between the age and opinion that SMEs in other EU countries have lower interest rates from credits than Slovak. SMEs.

\section{RESULTS AND DISCUSSION}

Literature research indicates the risk of a change of an interest rate is a considerable business risk that SMEs and young entrepreneurs face, which is also confirmed by the newest study of the OECD (2014). This document signed as one of the barriers for young entrepreneurs in European Union poor understanding of the credit market (e.g. loan application process, interest rates, time value of money, etc.) and considers interest rate risk as a relevant business risk of SMEs in Europe.

The study (OECD, 2014) informs: "The impact of the crisis and new banking regulations The economic crisis has dragged on in Europe since 2008, firstly through the failure and retrenchment of financial institutions and then because of the sovereign debt crisis. The crisis has had a severe impact on small business financing. Loan rejections at EU-27 aggregate level rose from 12\% to 18\% between the first and second half of 2009 and then fell back to 11\% in 2010 and 2011. Loan terms for small firms also worsened comparatively to large firms, and the interest rate spread between SMEs and large enterprises widened."

They (OECD, 2014) also declares that banks provide more finance to people with large personal wealth which further penalises women, young and ethnicminority entrepreneurs. In principle, banks could apply higher interest rates to compensate for the higher risk-profile of disadvantaged entrepreneurs.

\subsection{The impact of age on the interest rate risk}

The first, we examine the relation between the age and the interest rate risk (H1). The aim was to research if the young entrepreneurs have a different opinion in comparison with the other age groups of entrepreneurs. We postulated that the age is a significant factor that older entrepreneurs are more experienced in this area and perceive the interest rate risk more intensively. 
Table 3 Pearson chi-square calculation according to the age

\begin{tabular}{|l|c|c|c|c|c|c|}
\hline \multicolumn{7}{|c|}{ Do you know how to protect the firm against a change of interest rate } \\
\hline & \multicolumn{2}{|c|}{ Yes } & \multicolumn{2}{c|}{ Not } & \multicolumn{2}{c|}{ Total } \\
\cline { 2 - 8 } & $\%$ & $\begin{array}{c}\text { Absolute values } \\
(\text { AV) and chi- } \\
\text { square subtotals }\end{array}$ & $\%$ & $\begin{array}{c}\text { AV and chi-square } \\
\text { subtotals }\end{array}$ & $\%$ & AV \\
\hline To 35 & 22.09 & $36^{*}(45.4)[1.95]$ & 77.91 & $127(117.6)[0.75]$ & 100,00 & 163 \\
\hline 36 and more & 31.27 & $86(76.6)[1.15]$ & 68.73 & $189(198.4)[0.45]$ & 100,00 & 275 \\
\hline Total & - & 122 & - & 316 & 100,00 & 438 \\
\hline $\begin{array}{l}\text { Pearson } \\
\text { chi-square } \chi^{2}\end{array}$ & & 4.2981 & p- value & $0.038154<0.05$ & DGF** & 1 \\
\hline
\end{tabular}

*absolute numbers of respondents

**degrees of freedom

Source: own processing research data

At the beginning we investigate if they know how to protect the firm against the change of the interest rate. We considered 3 age categories. Chi-square statistic is $\chi^{2}=4.7096=\chi^{2}{ }_{0,05}$ with 1 dgf., the p-value is 0.094914 , at the base of this result we reject working alternative hypothesis H1. Having this result we decided to merge group $36-45$ and 45 and more. After the merge ofthe research data (Table 3) we found statistically significant differences between these two groups of entrepreneurs - up to 35 and 36 and more. This calculation brings evidence about statistically significant dependence between the age and ability of the company to protect the firm against the change of the interest rate. Value of chi-square statistic is $\chi^{2}=4.2981=\chi^{2} 0,05$ with 1 dgf. The $p$-value of 0.038154 indicates that the result is significant at $p<0.05$.

Table 4 Comparison of Pearson chi-square calculations among the chosen age groups in relation to the interest rate risk

\begin{tabular}{|c|c|c|c|c|}
\hline \multicolumn{5}{|c|}{ Ability to protect the firm against the change of interest rate } \\
\hline & Yes in $\%$ & Not in $\%$ & Chi-square & $p$-value \\
\hline To 35 & 22.09 & 77.91 & \multirow{3}{*}{4.7096} & \multirow{3}{*}{$0.094914>0.05$} \\
\hline $36-45$ & 33.33 & 66.67 & & \\
\hline 46 and more & 29.81 & 70.19 & & \\
\hline To 35 & 22.09 & 77.91 & \multirow{2}{*}{4.2981} & \multirow{2}{*}{$0.038154<0.05$} \\
\hline 36 more & 31.27 & 68.73 & & \\
\hline
\end{tabular}

Source: own processing research data

Despite of the initial negative calculation after merging the data we confirm working alternative hypothesis $\mathbf{H 1}$ at $95 \%$ level of probability. The biggest differences are in the group up to 35 and more than 35 years old. We present the comparison of chi-square calculations in different age groups in Table 4. 


\subsection{The impact of the age on the opinion that SMEs in other EU countries face the lower interest rate risk than Slovak SMEs}

In this part, we examined the dependence between the age and the opinion of domestic SMEs that SMEs in other EU countries have better interest rates than Slovak SMEs. We made comparison in the same way as in a previous cause. At the beginning, we found statistically significant differences among three age groups of entrepreneurs and then, between two groups (up to 35 and 36 and more - Table 5). In both cases, we found statistically significant dependence between the age and the opinion that SMEs in other EU countries have lower interest rates than SMEs in Slovakia.

Table 5 Pearson chi-square calculation according to the age

\begin{tabular}{|c|c|c|c|c|c|c|c|c|}
\hline \multicolumn{9}{|c|}{ SMEs in other EU countries have lower interest rates } \\
\hline & \multicolumn{2}{|c|}{ Agree } & \multicolumn{2}{|c|}{ Disagree } & \multicolumn{2}{|c|}{ Neutral position } & \multicolumn{2}{|c|}{ Total } \\
\hline & $\%$ & $\begin{array}{c}\text { AV and } \\
\text { chi-square } \\
\text { subtotals }\end{array}$ & $\%$ & $\begin{array}{c}\text { AV and } \\
\text { chi-square } \\
\text { subtotals }\end{array}$ & $\%$ & $\begin{array}{c}\text { AV and } \\
\text { chi-square } \\
\text { subtotals }\end{array}$ & $\%$ & $\mathrm{AV}$ \\
\hline To 35 & 36.81 & $\begin{array}{c}60 \\
(69.59) \\
{[1.32]}\end{array}$ & 3.68 & $\begin{array}{c}6 \\
(9.30) \\
{[1.17]}\end{array}$ & 59.51 & $\begin{array}{c}97 \\
(84.11) \\
{[1.98]}\end{array}$ & 100.00 & 163 \\
\hline 36 and more & 46.18 & $\begin{array}{c}127 \\
(117.41) \\
{[0.78]}\end{array}$ & 6.91 & $\begin{array}{c}19 \\
(15.70) \\
{[0.70]}\end{array}$ & 46.91 & $\begin{array}{c}129 \\
(141.89) \\
{[1.17]}\end{array}$ & 100.00 & 275 \\
\hline Total & - & 187 & - & 25 & - & 229 & 100,00 & 438 \\
\hline
\end{tabular}

Source: own processing research data

The value of chi-square statistic is $\chi^{2}=7.1228=\chi_{0,05}^{2}$ with 2 dgf. The $p$-value of 0.028399 indicates that the result is significant at $p<0.05$ so we confirm alternative hypothesis $\mathbf{H} 2$ at $95 \%$ level of probability. There are statistically significant differences among all three groups of entrepreneurs. If we change distribution of the age groups (Table 6), we are still successful in confirming alternative hypothesis $\mathrm{H} 2$. 
Table 6 Comparison of Pearson chi-square calculations among the chosen age groups in relation to the interest rate risk

\begin{tabular}{|c|c|c|c|c|c|}
\hline \multicolumn{6}{|c|}{ SMEs in other EU countries have lower interest rates } \\
\hline & Yes in $\%$ & Not in $\%$ & $\begin{array}{l}\text { Neutral } \\
\text { position in } \%\end{array}$ & Chi-square & p-value \\
\hline To 35 & 36.81 & 3.68 & 59.51 & \multirow{3}{*}{9.761} & \multirow{3}{*}{$0.044651<0.05$} \\
\hline $36-45$ & 51.75 & 7.02 & 41.23 & & \\
\hline 46 and more & 42.24 & 6.83 & 50.93 & & \\
\hline To 35 & 36.81 & 3.68 & 59.51 & \multirow{2}{*}{7.1228} & \multirow{2}{*}{$0.028399<0.05$} \\
\hline 36 and more & 46.18 & 6.91 & 46.91 & & \\
\hline
\end{tabular}

Source: own processing research data

In both cases the research findings confirm statistically significant dependence between the age and the perception of the interest rate risk. This result is contrary to the findings of Slovenian researcher Slavec (2014), who doesn't consider the age for a relevant factor in relation to credit risk. Our findings are conformal with the results of the majority of studies that prove significant relations between these two factors, e.g. surveys of Bottazzi et al. (2014) and Vos et al. (2007). They bring evidence that younger firms face the financial and credit risk more intensively than older and larger firms. The authors Lazányi (2014), Dong and Men (2014), Bougheas et al. (2006), Pickernell et al. (2011) and Riding et al. (2012) present the opinion that younger entrepreneurs the credit risk and interest rate risk more intensively than older ones. Younger entrepreneurs pay higher interest rates because they are of a smaller firm size and their liquidity to pay in time is lower than of the older entrepreneurs. Neuberger and Räthke-Döppner (2014) in their study compare the interest rate in the region of East Germany with stress on demographic indicators. They find out the results that young entrepreneurs are more likely to pay higher interest rates because their businesses are smaller and their liquidity to pay in time is lower than of the older entrepreneurs. Also, Oliveira and Fortunato (2006), Werner and Faulenbach (2008) and Hegarty and Jones (2008) bring similarly statements. Coleman et al. (2014) proved the owner age is significant factor in explaining the composition of young firm capital structure. They state older individuals are more risk averse and they use debt financing less than younger ones.

Studies presented in the literature review, in research results and also in the survey of OECD (OECD , 2014) indicate that the group of young entrepreneurs and start-ups is more threatened by the credit and interest rate risk than older ones. They are more risky clients so banks apply higher interest rates to compensate for the higher risk-profile of disadvantaged entrepreneurs. Despite of the significant risk it is important to realize they are referred to as drivers of innovation (Belás and Sobeková, 2016; Colombo, Cumming and Vismara, 2016). If the state supports them by appropriate tools it could lead to reducing the interest rate risk for start-ups and young entrepreneurs. Our research team assumes that support of the young entrepreneurs by government could lead to the strong support of business development and make it easier to obtain external banking capital. This will support innovative companies and helps to increase the competitiveness of the Slovak economy. 
At the base of the research findings we recommend to policy makers to eliminate the interest rate risk for young entrepreneurs to support the segment of young entrepreneurs and start-ups by special tools e.g.: guarantees for risky projects, supporting the venture capitalists and business angles in the region by special tools (for example tax and insurance relief) for a greater supply of venture finance and support the financing of venture and innovative projects that help to increase competitiveness of the country. This proposal is recommend also by authors Sobeková, Sipko and Solík (2014). They consider the lack of venture capital to be one of the key barriers of young entrepreneurs. They often have problems with a raising interest rate because of their higher risk profile and lack of guarantees. State guarantees on risky projects and for young companies with a short history allow the banks to provide loans to young entrepreneurs even if they have a higher risk-profile. Now there are special types of guarantees provided by Slovak guarantee and development banks but a majority of companies are still not well informed about its activities (Majková, 2008). The Slovak Republic was a co-founder of four state-private venture funds that support financing of innovative projects. We agree with the authors Colombo, Cumming and Vismara (2016, p. 21) who state: "Policy makers consider government venture capital programs to be an important part of a broader economic development strategy and to address the problems of financing gaps by intervening in multiple areas."

\section{CONCLUSION}

The main objective of the paper was to bring scientific evidence that the age of the entrepreneur should be considered as a factor with the significant impact on the one part of credit risk of the company- the risk of the change of interest rate - in Slovakia. This hypothesis was supported by many authors and studies presented in the literature review of the paper. It is obvious that younger entrepreneurs are more risky for banks. They pay higher interest rates because they are of a smaller firm size and their liquidity to pay in time is lower than of the older entrepreneurs. The basic finding of the research team agrees with them. The age has a significant impact on the interest rate risk. The history of doing business with younger entrepreneurs is mostly short. They are less experienced and often have a worse ability to protect the firm against the changes of the interest rate. It seems that older entrepreneurs also mostly agree with the opinion that SMEs in other EU countries have lower interest rates. In both cases, we found that the biggest differences are between the group up to 35 and 36 and more. This fact indicates that young entrepreneurs face the interest rate risk more intensively than other age groups of entrepreneurs.

The solution of the problem lies in hands of the government. On the one hand the state could decrease the high risk profile of young entrepreneurs by providing guarantees for loans on innovative products and services. On the other hand it could sustainably supply the formal and informal venture capital on the Slovak market that may cause the external finance to be affordable for them. A support of young and innovative companies will lead to increasing global competitiveness of the Slovak Republic.

The strength of the research was in the size and the homogeneity of the selection sample. However, the research has some weaknesses. The most important is the fact that respondents fulfilled the questionnaire online, and we were unable to organize a more detailed face to face interview. 
The future direction of the presented research will be focused on a comparative analysis of the entrepreneurial perception of the financial and credit risk in a wider geographical area of the countries of V4 - the Czech Republic, Slovakia, Hungary and Poland.

\section{Acknowledgement}

This research paper was funded from the project titled "Financing of young entrepreneurs and innovative companies with focusing on venture and private equity capital in Slovakia and EU" in the frame of the granting program of the Grant Agency of the Academic Alliance under the Grant agreement number 3/2016 and "SMEs in Slovakia - financial and credit risks" in the frame of the granting program of the Grant Agency of the Academic Alliance under the Grant agreement number 1/2016 and internal grant of Pan-European University in Bratislava named "Financing of innovative SMEs in Slovakia with focusing on investor's money with following comparison financing of innovation in the European Union."

\section{References}

1. Abor, J. Y., Agbloyor, E. K., \& Kuipo, R. (2014). Bank finance and export activities of Small and Medium Enterprises. Review of Development Finance. 4(2), 97-103. DOI:10.1016/ j.rdf.2014.05.004

2. Beck, T., \& Demigruc-Kunt, A. (2006). Small and medium-size enterprises: Access to finance as a growth constraint. Journal of Banking \& Finance, 30(11), 2931-2943. DOI: 10.1016/j.jbankfin.2006.05.009

3. Belás, J., \& Sobeková Majková, M. (2016). Výžnamné determinant kvality podnikatel’kébo prostredia MSP. Georg: Žilina.

4. Belás, J., Bartoš, P., Ključnikov, A., \& Doležal, J. (2015b). Risk perception differences between micro-, small and medium enterprises, Journal of International Studies, 7(3), 20-30. DOI: $10.14254 / 2071-8330.2015 / 8-3 / 2$

5. Belás, J., Demjan, V., Habánik, J., Hudáková, M., \& Sipko, J. (2015a). The Business Environment of Small and Medium-sized enterprises in Selected Regions of the Czech Republic and Slovakia, E \& M EKONOMIE A MANAGEMENT, 18 (1), 95 - 110. DOI:

6. Bena, J., \& Ondko, P. (2012). Financial development and the allocation of external finance. Journal of Empirical Finance, 19(1), 1-25. DOI:10.1016/j.jempfin.2011.11.002

7. Bhaird, C.M. (2010). Resourcing Small and Medium Sized Enterprises, Berlin: Springer Verlag.

8. Bottazzi, G., Secchi, A., \& Tamagni, F. (2014). Financial constraints and firm dynamics. Small Business Economics, 42(1), 99-116.

9. Bougheas, S., Mizen, P., \& Yalcin, C. (2006). Access to external finance: Theory and evidence on the impact of monetary policy and firm-specific characteristics. Journal of Banking and Finance, 30(1), 199-227

10. Cheng, M. E., \& Tang, Y. (2012, December). Research on the Small and Medium-sized Enterprises Financing Problems. In Proceedings of the sixth international symposium - The development of small and medium-sized enterprises, 93-97.

11. Coleman, S., Cotei, C., \& Farhat, J. (2014). The debt-equity financing decisions of U.S. startup firms. Journal of Economics and Finance, 40(1), 105 - 126. DOI:10.1007/s12197-014$9293-3$ 
12. Colombo, M., Cumming, D. J., \& Vismara. S. (2016). Governmental venture capital for innovative young firms. The Journal of Technology Transfer. 41(10), 10 - 24. DOI:10.1007/ s10961-014-9380-9

13. Constantinidis, C., Cornet, A., \& Asandei, S. (2006). Financing of women-owned ventures: The impact of gender and other owner- and firm-related variables. Venture Capital. 8(2), 133-57. DOI:10.1080/13691060600572557.

14. Dong, Y., \& Men, C. (2014). SME financing in emerging markets: firm characteristics, banking structure and institutions. Emerging Markets Finance and Trade, 50(1), 120-149. dx.doi. org/10.15240/tul/001/2015-1-008

15. Freel, M., Carter, S., Tagg, S., \& Mason, S. (2010). The latent demand for bank debt: Characterising "discouraged borrowers". Small Business Economics, 38(4), 399-418. DOI:10.1007/s11187-010-9283-6

16. Gambini, A., \& Zazzaro, A. (2013). Long-lasting bank relationships and growth of firms. Small Business Economics, 40(4), 977-1007.

17. Garwe, D. K., \& Fatoki, O. (2012). The impact of gender on SME characteristics and access to debt finance in South Africa, Development Southern Africa, 29(3), 448 - 461. DOI:10.1080/0376835X.2012.706040.

18. Hegarty, C., \& Jones, C. (2008). Graduate entrepreneurship: more than child's play. Education+Training, 50(7), 626-637.

19. Hernández-Cánovas, G., \& Martínez-Solano, P. (2010). Relationship lending and SME financing in the continental European bank-based system. Small Business Economics, 34(4), 465-482.

20. Irwin, D., \& Scott, J. M. (2010). Barriers faced by SMEs in raising bank finance. International journal of entrepreneurial behavior \& research, 16(3), 245-259.

21. Jakubec, V., Sobeková Majková, M., \& Solík, J. (2012). Potreby mladých podnikatelov a prekáákey vichpodnikaní. Bratislava: ZMPS.

22. Karpak, B., \& Topcu, I. (2010). Small medium manufacturing enterprises in Turkey: An analytic network process framework for prioritizing factors affecting success. International Journal of Production Economics, 125(1), 60-70.

23. Ključnikov, A., \&Belás, J. (2016).Approaches of Czech Entrepreneurs to Debt Financing and Management of Credit Risk.Equilibrium. Quarterly Journal of Economics and Economic Policy, 11(2), 343-365. DOI: http://dx.doi.org/10.12775/ EQUIL.2016.016

24. Kljucnikov, A., Belás, J., Kozubíková, L., \& Paseková, P. (2016). The Entreprenurial Perception of SME Business Environment Quality in the Czech Republic. Journal of Competitiveness, 8(1).

25. Kozubíková, L., Belás, J., Bilan, Y., \& Bartos, P. (2015). Personal characteristics of entrepreneurs in the context of perception and management of business risk in the SME segment. Economics \& Sociology, 8(1), 41.

26. Krasniqi, B. A. (2010). Are small firms really credit constrained? Empirical evidence from Kosova. International Entrepreneurship and Management Journal, 6(4), 459-479. 
27. Lazányi, K. (2014). Entrepreneurs of the future. Serbial Journal of Management, 9(2), 149-158. DOI:10.5937/sjm9-6257

28. Majková, M. (2008). Možnosti financovania malých a stredných podnikov v SR. Tribune: Brno, 2008.

29. Mama, A.T., \& Ewoudou, J. (2010). Who is credit constrained among denied or discouraged borrowers? Retrieved January 18, 2016, from www.econrsa.org/papers/w_papers/wp199.pdf.

30. Mercieca, S., Schaeck, K., \& Wolfe, S. (2009). Bank Market Structure Competition and SME Financing Relationship in European Regions. Journal of Financial Services Research, 36 (2-3), 137-155.

31. Mijid, N. (2009). Gender, race and credit rationing of small businesses evidence from the 2003 survey of small business finance. Retrieved January 18, 2016, from www.kauffman.org/research-andpolicy/kdfp/fellows.aspx

32. Neuberger, D., \& Räthke-Döppner, S. (2014). The role of demographic in small business loan pricing. Small Business Economics, 44(2), 411-424.

33. Nkundabanyanga, S. K., Kosozi, D., Nalukenge, I., \& Tauringana, V. (2014). Lending terms, financial literacy and formal credit accessibility. International Journal of Social Economics, 41(5), 342-316.

34. OECD/European Union. (2014). Policy Brief on Access to Business Start-up Finance for Inclusive Entrepreneurship. Luxembourg: Publications Office of the European Union. Retrieved from https://www.oecd.org/cfe/leed/Finacing $\% 20$ inclusive $\% 20$ entrepreneurship $\% 20$ policy $\% 2$ Obrief $\% 20$ EN.pdf

35. Oliveira, B., \& Fortunato, A. (2006). Firm Growth and Liquidity Constraints: A Dynamic Analysis. Small Business Economics, (27)2-3, 139-156. DOI: 10.1007/s11187-006-0006-y

36. Pickernell, D., Packham, G., Jones, P., Miller, C., \& Thomas, B. (2011). Graduate entrepreneurs are different: They access more resources? International Journal of Entrepreneurial Behaviour and Research. 17(2), 183-202

37. Riding, A., Orser, B. J., Spence, M., \& Belanger, B. (2012). Financing new venture exporters. Small Business Economics, 38(2), 147-163

38. Roper, S., \& Scott, J. M. (2009). Perceived financial barriers and the start-up decision: An econometric analysis of gender differences using GEM data. International Small Business Journal, 27(2), 149-71.

39. Rostamkalaei, A., \& Freel, M. (2015). The cost of growth: small firms and the pricing of bank loans. Small Business Economics, 46(2), 255-272.

40. Slavec, A. (2014). Bank financing and trade credit use of Slovenian small firms: An empirical examination. Transformations in Business and Economics, 13(2), 91-101.

41. Sobeková Majková, M. (2011), Analýza bariér a faktorov financovania malých a stredných podnikov v SR. Journal of Economics, 59 (10), 1028-1032

42. Sobeková Majková, M., Sipko, J., \& Solík, J. (2014). The analysis of chosen business obstacles and problems with the financing of young entrepreneurs in Slovakia. Economics \& Sociology, 7(3), 90 - 103. DOI:10.14254/2071-789X.2014/7-3/7 
43. Steinerowska-Streb, I., \& Steiner, A. (2014). An Analysis of External Availability on SMEs Decision Making. Thunderbird International Business Review, 56 (4), 373-386.

44. van der Zwan, P., Thurik, R., \& Grilo, I. (2010). The entrepreneurial ladder and its determinants. Applied Economics, 42(17), 2183-2191.

45. Vos, E., Yeh, A. J.-Y., Carter, S., \& Tagg, S. (2007). The happy story of small business financing. Journal of Banking and Finance, 31(9), 2648-2672. DOI: 10.1016/ j.jbankfin.2006.09.011

46. Werner, A., \& Faulenbach, N. (2008). Das Gründungsverbalten Älterer: Eine empirische Analyse mit den Daten des Gründerpanels des IfM Bonn (No. 184). Institut für Mittelstandsforschung (IfM) Bonn.

\section{Contact information:}

Ing. Monika Sobeková Majková, PhD.

Pan-European University

Faculty of Economics and Business

Tematínska 10, Bratislava

E-mail:monika.majkova@centrum.sk. 